\title{
Mechanical properties of lightweight concrete with sintered aggregate
}

\author{
Anna M. Rogowska ${ }^{1, *}$, Pawet $M$. Lewiński ${ }^{1}$ \\ ${ }^{1}$ Instytut Techniki Budowlanej, 00-611 Filtrowa 1 Warszawa, Poland
}

\begin{abstract}
The objective of this paper is the determination of short-term properties of lightweight concrete with sintered aggregate. The aggregate material comes from the recycling of ashes from power plants, which yield granules after processing. The research was planned based on two concrete mixes. A series of tests was carried out in the ITB Laboratory of Building Structures, Geotechnics and Concrete. As a result of these tests, the following parameters were determined: secant modulus of elasticity and cylinder strength of concrete, cube strength of concrete, axial tensile strength, splitting tensile strength, flexural strength and concrete shrinkage. Knowledge of the tested parameters is necessary when designing prestressed structures, as well as accepting proven values for static calculations when designing complex engineering structures, including prestressed elements made of lightweight concrete.
\end{abstract}

\section{Introduction}

Due to its properties, lightweight concrete has found wide application in construction, including in high-rise buildings, prefabricated structures, bridges and oil platforms. Lightweight concrete constitutes a group of materials with different properties. It is necessary to verify their mechanical properties thoroughly. There are currently no research standards for lightweight concrete. Lightweight aggregate concrete is still a problematic material for use in construction. Little knowledge about such materials and lack of tests discourage designers from using it in projects.

The issue of lightweight aggregates has been studied extensively in a number of significant publications, including [1]. They presented the properties of many types of aggregate and concrete based on ash aggregates, as well as lightweight concrete. The work [2] describes in detail the properties of lightweight concretes, including concretes with the same aggregates as those discussed in the present research.

Due to the lack of standards and difficulties in implementation, tensile tests and the secant modulus of elasticity of concrete tests are performed rarely. However, these results are very important for the structural design. Knowledge of originally tested parameters is necessary for designing structures according to the standard [12], likewise accepting proven values for static calculations when designing complex engineering structures, including prestressed elements made of lightweight concrete.

\footnotetext{
* Corresponding author: a.rogowska@itb.pl
} 
The aggregate material comes from recycled ashes from power plants, which features granules after processing. A program for testing strength parameters and mechanical properties of lightweight concrete with sintered aggregate with particularly favourable properties was developed. The research was planned on two concrete mixtures, analogous to the one in [3].

Concrete was produced in a concrete plant by means of a specialized mixer ensuring homogeneity of the mix. After pouring the prepared forms and appropriate care in laboratory conditions, the tests were carried out in accordance with the following procedures:

- secant modulus of elasticity of concrete in accordance with [6],

- compressive strength according to [7],

- axial tensile strength according to [8],

- tensile splitting strength according to [9],

- flexural strength according to [10],

- shrinkage according to [11].

\subsection{Concrete mixes}

Two concrete mixes LC1 and LC2 were prepared in the same way as in the paper [3]. Table 1 shows the recipe for the two types of the applied concrete mixes.

Table 1. Concrete mixes analogous to the one in [3]

\begin{tabular}{|c|c|c|}
\hline \multirow{2}{*}{ Component } & LC1 & LC2 \\
\hline & \multicolumn{2}{|c|}{ Volume $\left[\mathrm{kg} / \mathrm{m}^{3}\right]$} \\
\hline CEM I 42,5 N & 409 & 419 \\
\hline Aggregate Certyd & 775 & 802 \\
\hline Sand & 682 & 703 \\
\hline Water & 164 & 209 \\
\hline Admixture $B V 18$ & 3,7 & 3,8 \\
\hline Admixture SKY 686 & 3,7 & 3,8 \\
\hline
\end{tabular}

\subsection{Types of samples}

For the secant modulus of elasticity of concrete and axial tensile strength tests the samples coming from drilling with a $94 \mathrm{~mm}$ nominal diameter, $188 \mathrm{~mm}$ height were used.

For the remaining tests, the samples were prepared in accordance with the relevant standards as in Chapter 1. 


\section{Test results}

\subsection{Compressive strength}

The test results for compressive strength are given in Figure 1.

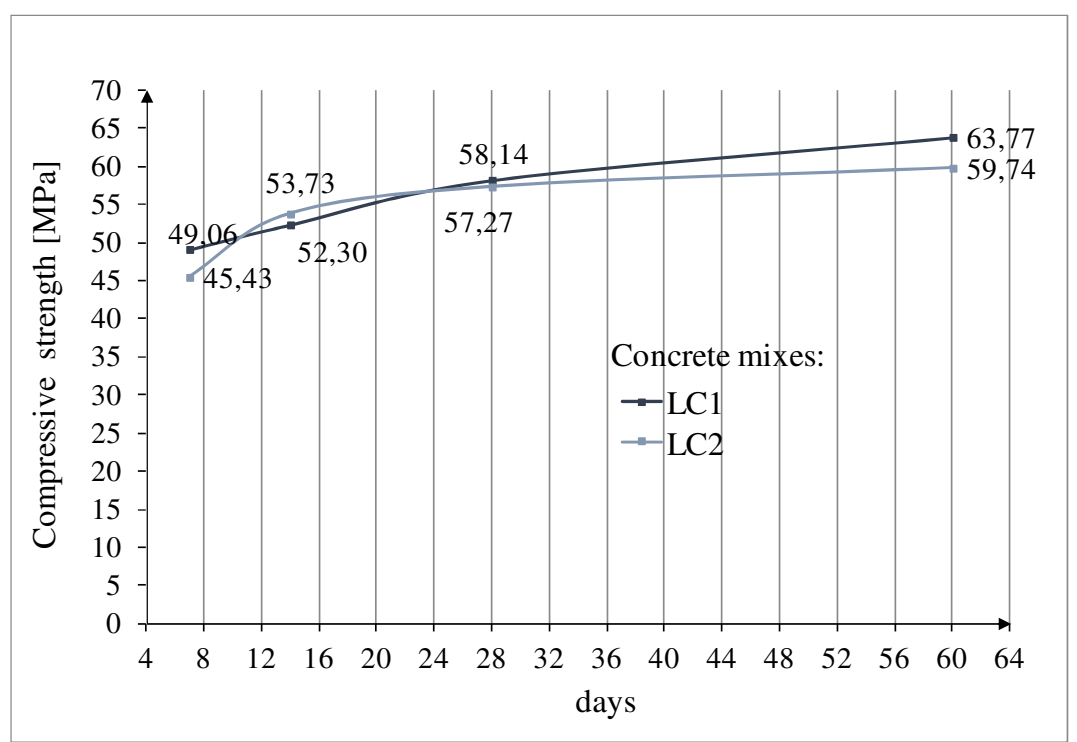

Fig. 1. The compressive strength test results.

The concrete mixes LC1 and LC2, seven days after the samples were prepared, met the LWAC 40/44 class according to [12], as shown in Figure 1. At the age of 28 days, these mixes reach two consecutive classes up to the LWAC 50/55 class in accordance with [12].

\subsection{Axial tensile strength}

The test results for axial tensile strength are given in Figure 2.

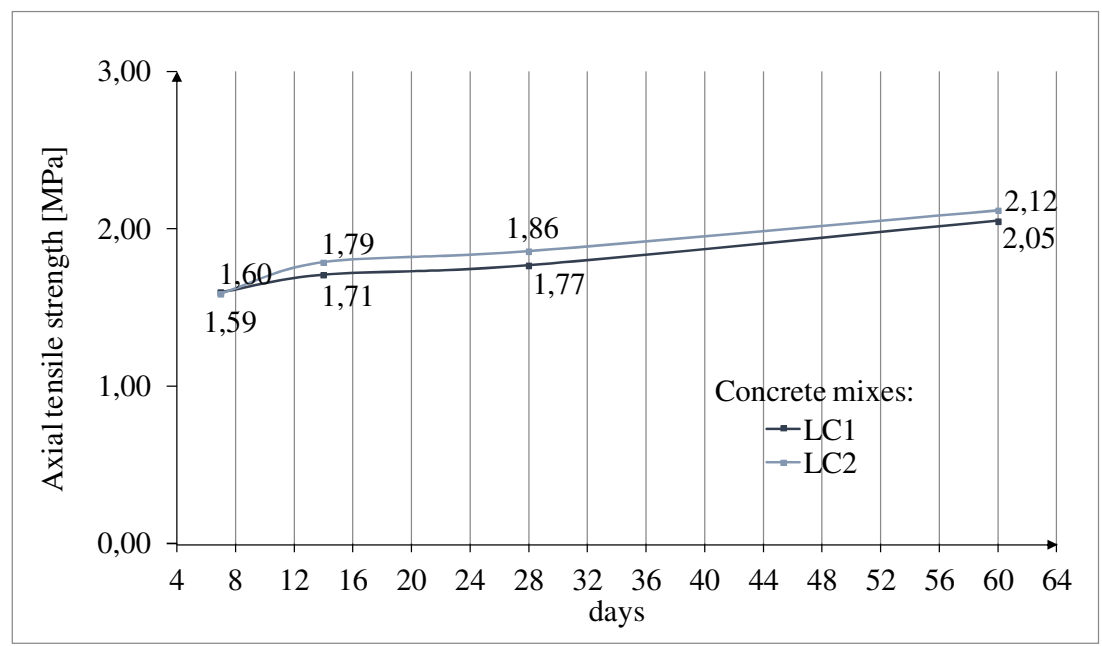

Fig. 2. The axial tensile strength test results. 
Seven days after the preparation of samples, the LC1 and LC2 mixes achieved the axial tensile strength of 1,6 MPa (see Fig. 2). After 28 days the strength increased by over $10 \%$.

\subsection{Tensile splitting strength}

The test results for the tensile splitting strength are given in Figure 3.

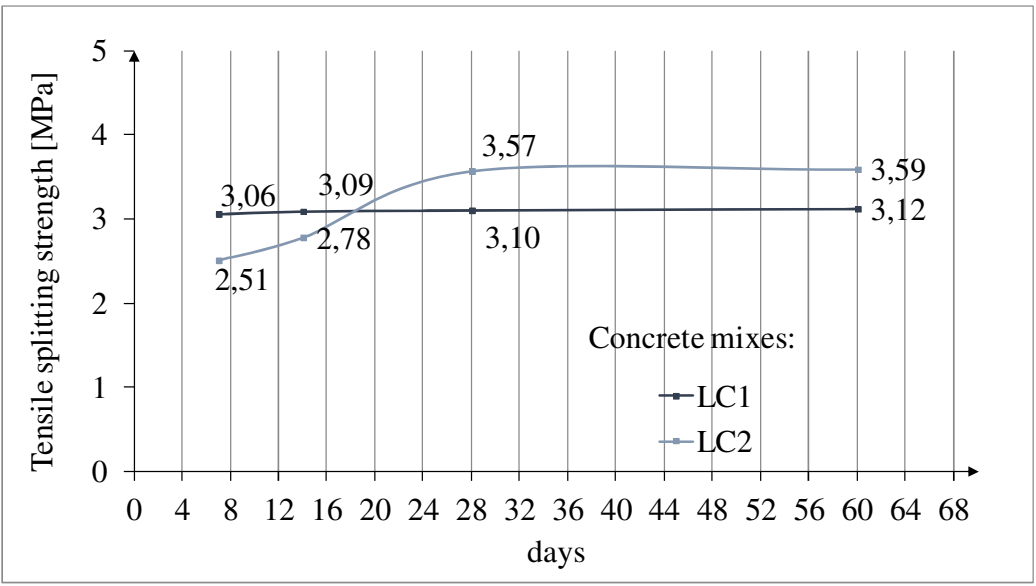

Fig. 3. The tensile splitting strength results.

The splitting strength results for the LC1 mix during 60 days were fairly constant. The results for the LC2 mix increased over $40 \%$ between $7^{\text {th }}$ and $28^{\text {th }}$ day.

\subsection{Flexural strength}

The test results for the flexural strength are given in Figure 4.

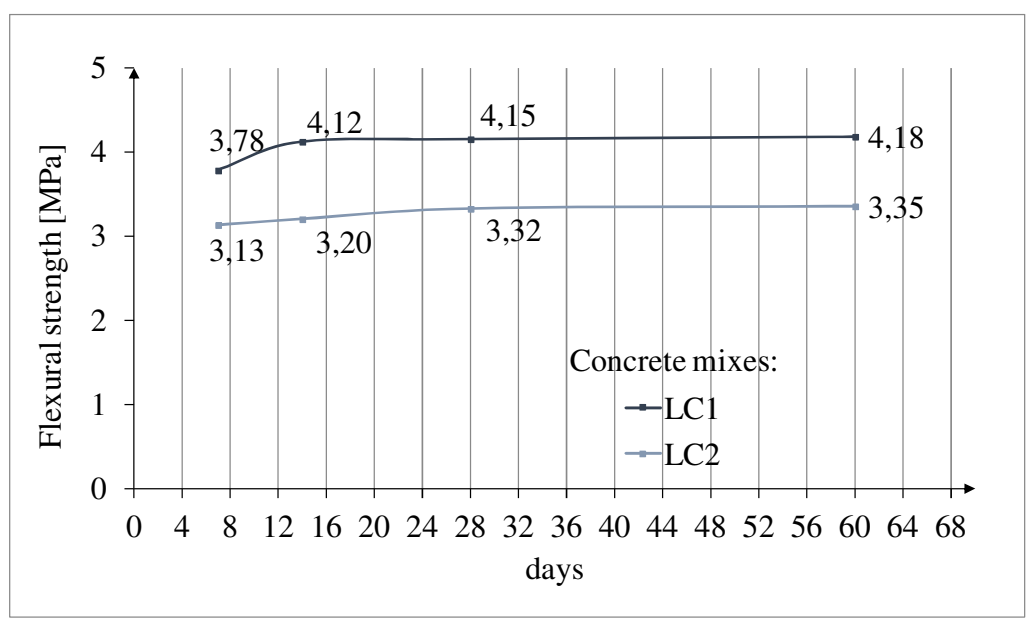

Fig. 4. The flexural strength results.

The flexural strength results for the LC2 mix during 60 days were fairly constant. The flexural strength results for the LC1 mix increased by over $10 \%$ between $7^{\text {th }}$ and $28^{\text {th }}$ day. 


\subsection{Secant modulus of elasticity}

The test results for the secant modulus of elasticity of concrete are given in Figure 5.

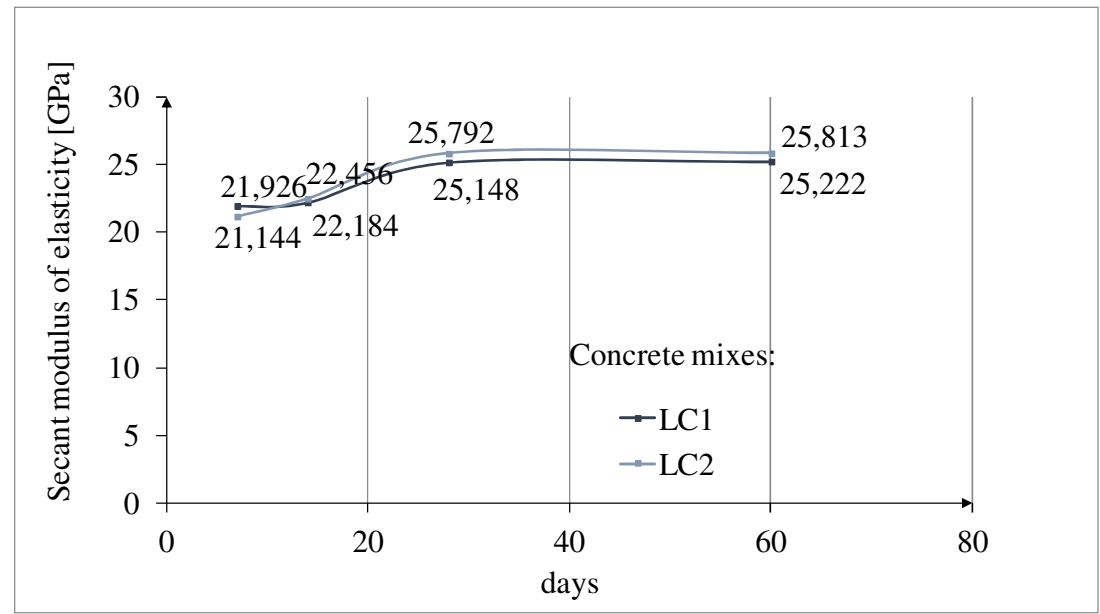

Fig. 5. The test results for the secant modulus of elasticity.

The test results for the LC1 and LC2 mixes showed similar growth over 60 days. The secant modulus of elasticity increased approximately by $13 \%$ between $7^{\text {th }}$ and $28^{\text {th }}$ day.

The test results for the secant modulus of elasticity in relation to compressive strength are given in Figure 6.

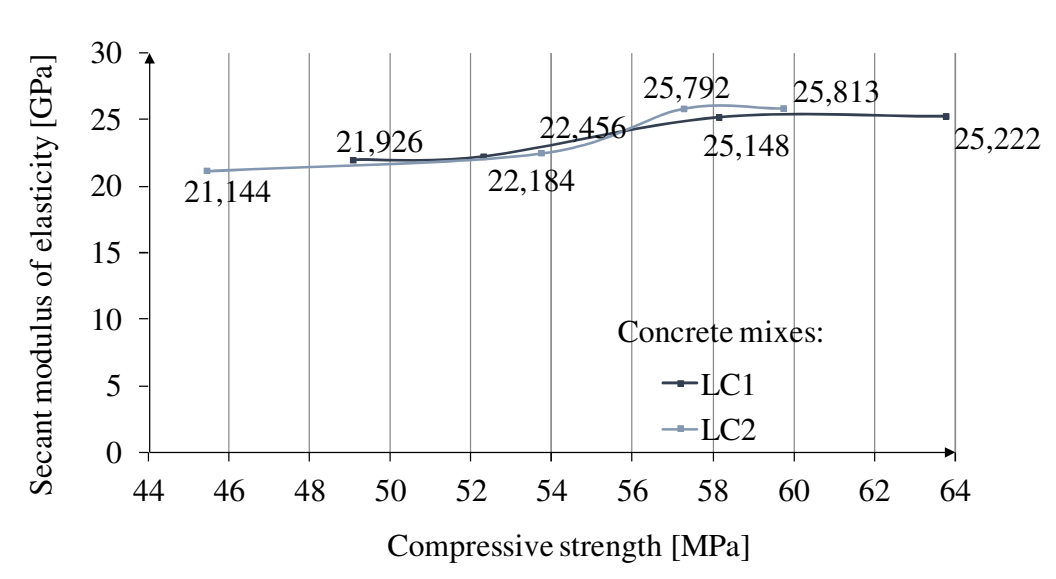

Fig. 6. The test results for the secant modulus of elasticity in relation to compressive strength. 


\subsection{Shrinkage}

The test results for the shrinkage are given in Figure 7.

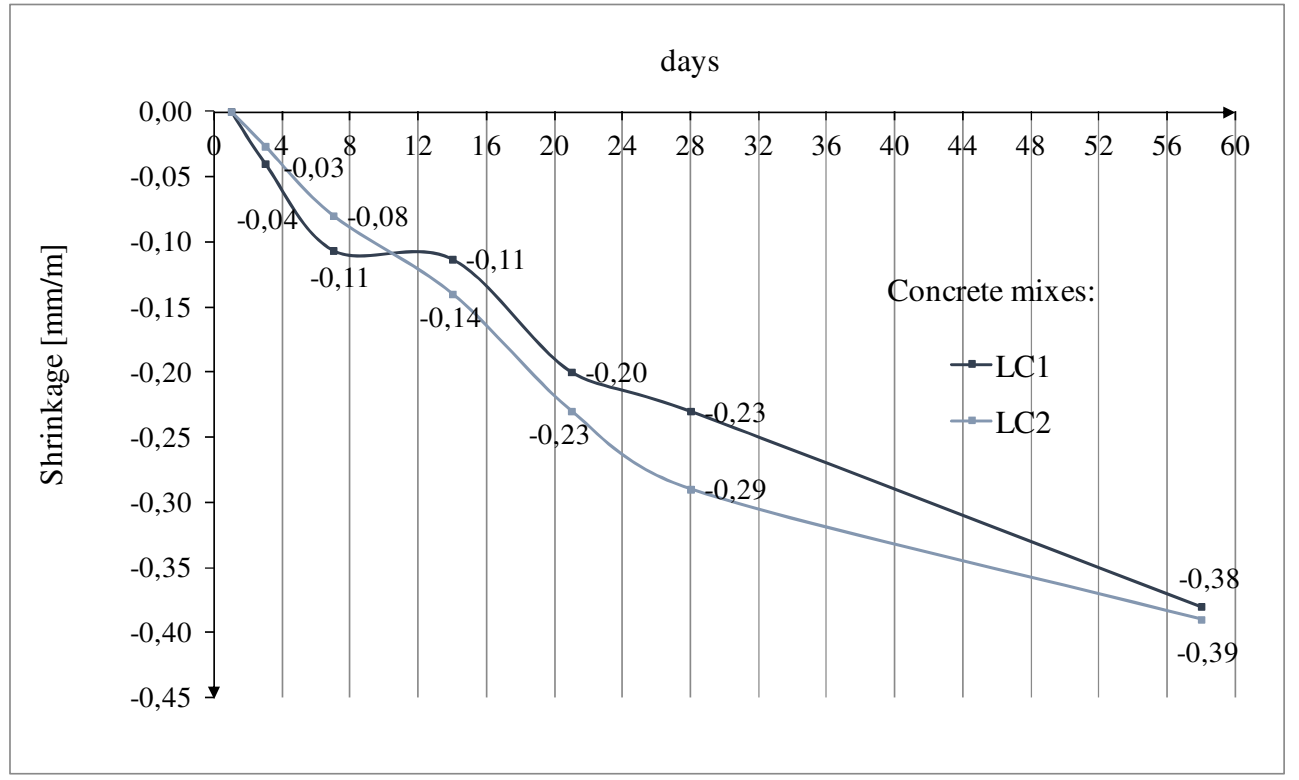

Fig. 7. The development of the shrinkage according to the tests.

Between $7^{\text {th }}$ and $28^{\text {th }}$ day, the LC1 mix had no shrinkage in these tests. The LC2 mix had a continuous shrinkage within 58 days. Ultimately, both types of concrete had consistent results after 58 days.

The mutual empirical relations of concrete secant elasticity modulus and axial tensile strength in relation to compressive strength as well as the development of these parameters in time and their mutual relationship (1) and (2), respectively, were proposed based on the CEB relationship (Equation (1)) and Feret's formula (Equation (2)).

$$
\begin{aligned}
& E_{c}=\beta\left(f_{c}\right)^{1 / 2} \\
& f_{t}=\alpha\left(f_{c}^{2}\right)^{1 / 3}
\end{aligned}
$$

Based on the research, the following experimental constants were determined: $\beta=3.2, \alpha=0.13$. The comparison of the test results for the secant modulus of elasticity of concrete with analytical results is outlined in Figure 8. 


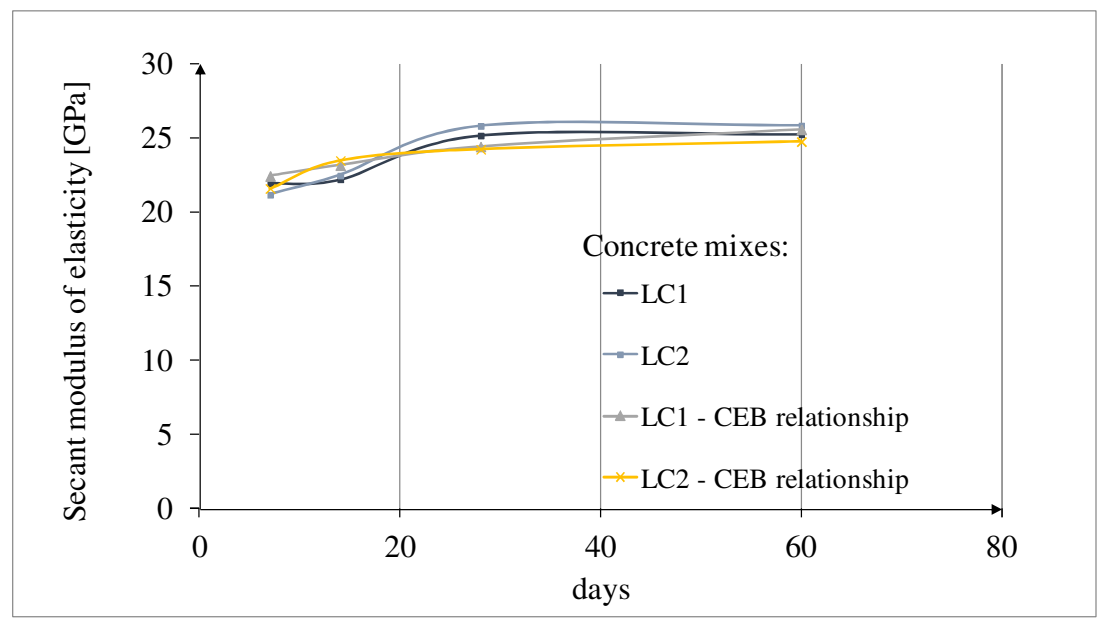

Fig. 8. The comparison of test results for secant elasticity modulus with analytical results.

The comparison of the test results for the axial tensile strength with analytical results is presented in Figure 9.

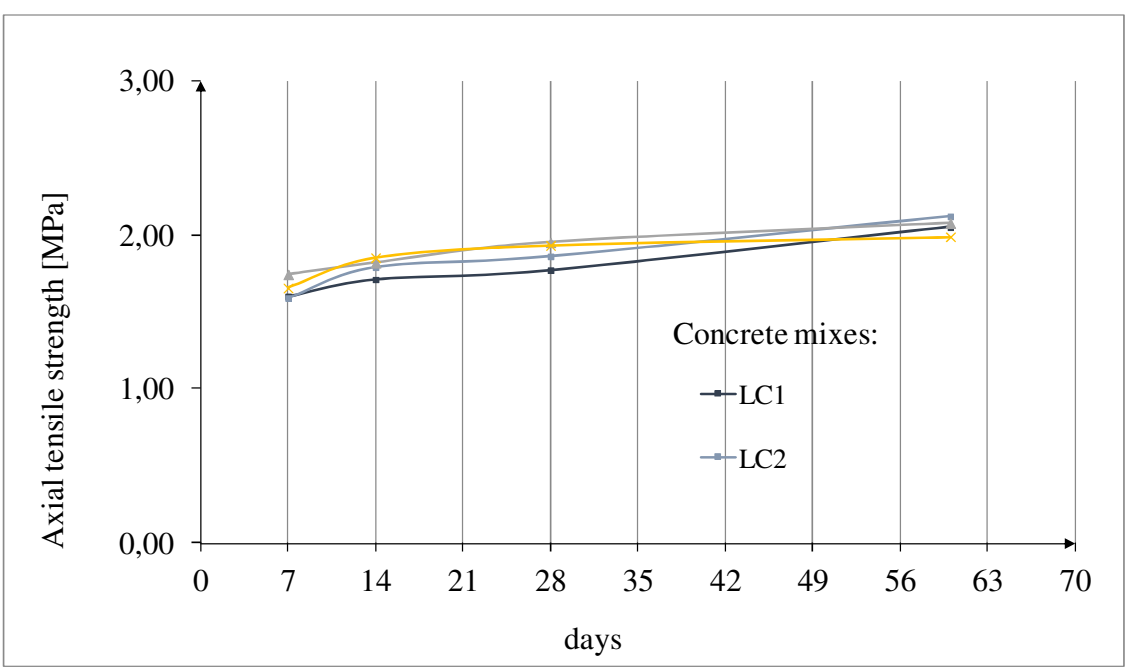

Fig. 9. The comparison of test results for axial tensile strength with analytical results.

\section{Conclusions}

The performed tests allowed to determine the aforementioned strength parameters of concretes with lightweight aggregate coming from ashes. In this work, the test results include readings taken within two months of making the mixes. The entire research process is expected to run for more than 300 days after the samples were made. The results obtained do not differ significantly from the results presented in the papers [4,5].

The mutual empirical relations of concrete tensile strength and secant elasticity modulus in relation to compressive strength as well as the development of these parameters and their mutual relationship in time were determined. The results are presented in the form of analytical formulas and graphs. 
Consequently, the preliminary research outputs give a broader view on the possibilities of exploiting the lightweight concrete with sintered aggregate in modern construction and the development of their strength parameters over the time. The presented results can be used in the design of lightweight concrete structures and components, especially prestressed structures, where knowledge of these results is necessary for the correct design of the structure. However, it should be remembered that the results were obtained in laboratory conditions. In case of using these results in practice, it is necessary to take into account the actual conditions in which the concrete is to be situated.

Moreover, the reuse of waste materials is now an environmental priority. As a result, the reuse of ashes for the production of concrete aggregate may, in the future, reduce the mining of raw materials and the use of natural aggregates in construction. The preservation of natural deposits also contributes to environmental protection.

However, it should be remembered that the results presented in this paper were obtained in consistent laboratory conditions. Built-in concrete exposed to various external factors may change its strength and mechanical properties. When using these results in practice, it is necessary to take into account the method of concrete production and the actual conditions under which concrete is to be laid.

\section{References}

1. L. Domagała, Konstrukcyjne lekkie betony kruszywowe. Monografia 462 (Wydawnictwo Politechniki Krakowskiej, Kraków, 2014).

2. S. Chandra, L. Berntsson, Lightweight aggregate concrete (Elsevier, 2002).

3. M. Mieszczak, R. Szydłowski, Badania lekkiego betonu kruszywowego z przeznaczeniem do konstruowania stropów dużej rozpiętości (Konferencja NaukowoTechniczna Konstrukcje Sprężone, Kraków, 2018).

4. M. Mieszczak, L. Domagała, Lightweight aggregate concrete as an alternative for dense concrete in post-tensioned concrete slab, (Mat. Sci. For. 926, 2018).

5. Ł. Sowa, M. Gołdyn, Ł. Krawczyk, T. Urban, The concept for determining punching shear capacity of LWAC slabs without shear reinforcement (Proceedings of the Symposium, 2019).

6. PN-EN 12390-13:2014-02 Testing hardened concrete - Part 13: Determination of secant modulus of elasticity in compression.

7. PN-EN 12390-3:2019-07 Testing hardened concrete - Part 3: Compressive strength of test specimens.

8. L. Brunarski, Badanie cech mechanicznych betonu na próbkach wykonanych w formach, Instrukcja 194/98 (ITB, Warszawa, 1998).

9. PN-EN 12390-6:2011 Testing hardened concrete - Part 6: Tensile splitting strength of test specimens.

10. PN-EN 12390-5:2019-08 Testing hardened concrete - Part 5: Flexural strength of test specimens.

11. PN-B-06714-23:1984 Mineral aggregates - Testing - Determination of volume changes by Amsler method.

12. PN-EN 1992-1-1:2008 Eurocode 2: Design of concrete structures - Part 1-1: General rules and rules for buildings. 